\title{
Industrial Law 4.0: Harmonization of Nature, Technology and Humans
}

\author{
Nunik Nurhayati, Khudzaifah Dimyati, Absori, Kelik Wardiono, Rina Nur \\ Widyastuti* $^{*}$
}

Faculty of Law, Universitas Muhammadiyah Surakarta

${ }^{*}$ Coressponding author. Email: rwidyastuti0@gmail.com

\begin{abstract}
In the face of the fourth industrial revolution, this article tries to explain the importance of the state creating industrial policies that benefit both humans and nature. This paper applies a normative technique to explain nature, technology, and humanity. Electric and clean car technology, renewable energy, smartgrid, IoT/IOE, Big Data, robots, AI, fintech, blockchain, VR, cybersecurity, and agtech/agricultural innovation are all examples of Industry 4.0. The state must be able to anticipate the negative effects of industrial operations in order to avoid the failure of the previous industrial revolution, which harmed persons and harmed the environment. The state must use its power to create regulations that regulate industrial operations and products in order to balance nature, technology, and humans.
\end{abstract}

Keywords: Industrial Law, Technology, Industry 4.0

\section{INTRODUCTION}

In simple terms, industry is a form of activity that converts raw materials into finished goods with the aim of increasing the value and benefits of an item. The more complex human needs, the more improved the performance of an industry becomes. Based on historical findings, industrial activities have existed since prehistoric times where many historical heritage items such as jewelry originating from shells and teeth from consumption products were made using special stones [1]. The findings came from Gua Kidang, Blora, Indonesia, which shows the technology of jewelry making using specially fstones.

In the Al-Qur'an compiled around the year $600 \mathrm{AD}$, there are several verses that convey industrial activities, for example, in QS. Al - Hadid verse 25: "... And We sent down iron, wherein is great military might and benefits for the people" which means that the iron can be used as a means for human work such as hoes, axes, saws, chisels, tools for plowing land and other equipment used for agricultural, carpentry and other tools needed by humans [2]. At that time, industrial activities still relied on tools that were run by human power so that the production was not large and not quickly completed due to human physical limitations.

Along with the development of science was born inventions in the form of machines which eventually were able to replace human power so that industrial activities were able to produce more in production and faster processing time. This was marked by the start of the first industrial revolution in Europe in the 18th century (1800 AD) with the creation of a steam engine by James Watt, which became the beginning of the emergence of manufacturing machines in the industrial era [3].

Then in the 20th century a second industrial revolution emerged with the emergence of electric power and motorcycles used as fuel for production machines that were able to improve the quality and quantity of the production of goods better and very quickly. Only in the 1970s did the world enter the third industrial revolution with the development of information technology and the onset of the rise of the Internet [3]. Many scientists and academics believe that the Internet of Things, which is based on cyber-physical systems, will usher in the fourth Industrial Revolution. [4] [5]. 


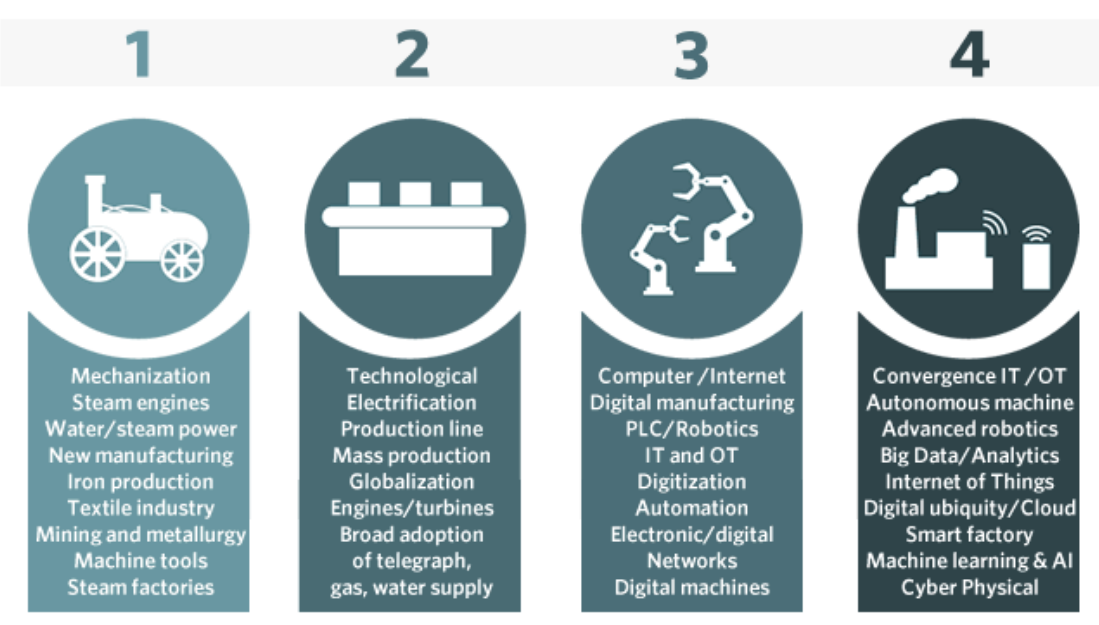

Figure 1. The four stages of the Industrial Revolution Source at https://www.i-scoop.eu/industry-4-0/

The first industrial revolution had both beneficial and negative consequences, particularly in terms of human life, such as the high rate of urbanization in industrial towns, which prompted rural populations (agricultural) to migrate to industrial cities and work in factories. Due to fierce competition, high demand for work, and low labor costs while the needs of life in the city were highly expensive, the negative influence of course affected the growth of unemployment and criminal activities. Not to mention the distinction between capital and labor owners, where economic inequality grew as capital owners became wealthier and laborers became poorer. The industrial revolution fostered the incidence of a range of crimes and disorder by promoting a poor quality of life and bad behaviors. Furthermore, during the industrial revolutions II and III, environmental degradation began to be perceived and acknowledged by the global society as a result of production activities that exploited nature.

The fourth industrial revolution was born as a result of the incomplete resolution of the problem as a result of the bad impact of the first to third industrial revolutions, which was predicted to have a negative impact on humans as well. The emergence of resistance to demographic and social changes, political instability, limited resources, natural disaster risks, and demands for the adoption of environmentally friendly technologies, according to Drath and Horch, is a country's challenge in implementing Industry 4.0 [6]. If it is unconquered then things that will not be expected will surely emerge, for example natural disasters due to the application of technology that is not environmental friendly.

Along with its detrimental influence, the industrial revolution, technological advancement, practical life, and other favorable effects were not anticipated. As a result, it is time to begin engineering as a means of reducing the bad effects of the industrial revolution, so that people can become subjects capable of controlling the appearance of negative effects from industrial activities, both on nature and on humans.

\section{COUNTRY AND INDUSTRY 4.0}

The industrial revolution is still continuing on, and the World Economic Forum 2018 in Davos-Klosters, Switzerland, provided a vital message about Industry 4.0, a new chapter that will use technology innovation to revolutionize all aspects of human life. Artificial intelligence, robotics development, "the Internet of Things," virtual reality, and three-dimensional printing machines are just a few examples of technical innovations that are propelling Industry 4.0 forward. [7]. When compared to earlier transformations, Industry 4.0 happened exponentially or extensively, impacting every industry in many nations and promising transformation across the entire production system and government. All parties must steer the change in the right direction so that the digitalization process benefits future generations. However, the interesting thing is that naming Industry 4.0 was a new idea that was announced with apriority [6], this is different from the previous industrial revolution that evoked the phenomenon first.

The term Industry 4.0 was first launched in 2011 when Hannover Fair was held in Germany in 2011. Kagermann, Lukas, \& Wahlster conveyed how a paradigm shift in industry would occur in the next decade, based on a cyber physical system in which Germany could become the first country in developing industry this type [8]. This was because Germany was very interested in Industry 4.0 because it was part of its High-Tech Strategy 2020 development strategy, which aimed to maintain Germany at the forefront of manufacturing. [9] In 2013, Kagermann, et al. compiled a Platform Industry 4.0 which aimed to make Germany the leading market and leading supplier of technological innovation in the world [10]. 
Several other countries contributed to the development of Industry 4.0, although they called it something else, such as Smart Factories, Industrial Internet of Things, Smart Industry, or Advanced Manufacturing. Regardless of the differences in their circumstances, they all had the same goal in mind: to improve the competitiveness of each country's industry in the face of a fast changing global market [11].

The concept of industrial internet was first offered in North America by General Electric in late 2012. This was viewed as a powerful integration between the physical and digital worlds that linked large analytical data with the Internet of Things in the health, manufacturing, public sector, transportation, and mining areas [12].

France's industrial policy was launched with the concept of "industrie du futur," or "future industry," which is based on five pillars: 1) cutting-edge technologies like additive manufacturing, virtual plants, IoT, and augmented reality, 2) assisting French businesses, particularly small and medium-sized businesses, in adapting to new technologies, 3) extensive employee training, 4) promotion of industrial standards, and 5) promotion of future-oriented French industry. [13].

China with the slogan 'Made in China 2025' began to be applied massively in 2015 [14]. It was started by the Chinese Ministry of Industry and Information Technology, in collaboration with many experts from the Chinese Academy of Engineering, with the goal of improving Chinese industry in a comprehensive way by copying the German Industry 4.0 concept and adapting it to Chinese conditions. The long-term goal is for China to restructure its manufacturing industry, shift its thinking from low-cost to high-quality products, and take over manufacturing dominance from Germany and Japan until 2035, then become an industrial giant in 2049. [15].

Industry 4.0 presents a potential for Indonesia's manufacturing sector to be revitalized, as well as a means of accelerating the country's aim of becoming one of the world's top ten economies. The Indonesian Ministry of Industry developed the "Making Indonesia 4.0" initiative to implement the strategy and Industry Roadmap 4.0 in Indonesia, which aims to provide clear direction and strategy for the future movement of Indonesian industry, with a focus on five sectors and ten national priorities. [16]. Food and beverages, textiles and clothing, automotive, chemicals, and electronics are the five industries that Indonesia will focus on in Industry 4.0. Meanwhile, ten Indonesian national priorities are: 1) improving goods and materials flow, 2) redesigning industrial zones, 3) accommodating sustainability standards, 4) empowering micro, small and medium enterprises, 5) building national digital infrastructure, 6) attracting foreign investment, 7) improving human resource quality, 8) developing innovation ecosystems,
9) incentives for technological investment, and 10) harmonization of rules and policies. [17].

\section{INDUSTRIAL TECHNOLOGY 4.0}

Experts predict Industry 4.0 has a large potential benefit and has a positive impact on a country's economy state, including:

a. Speed and flexibility of production, improving service to customers and increasing revenue; [11]

b. Product development becomes faster, actualizing individual demand in the form of product customization, flexible and fast production in responding to problems and resource efficiency; [18]

c. Improving productivity, encouraging revenue growth, increasing the need for skilled labor, and increasing investment; [19]

d. Ability to address unique consumer needs, dynamic engineering and business processes, optimal decision-making, and the development of new business models and ways to provide value; [10]

e. Realizing a cost-effective, efficient, smart, and on-demand manufacturing process. [20]

These benefits are predicted to occur due to technology sophistication in the era of Industry 4.0 covering electric and clean-vehicle, renewable energy, smartgrid, IoT / IoE, Big Data, robotics, AI, fintech, blockchain, VR, cybersecurity, and agtech / agricultural innovation [3]. This technology is frequently thought to be unrelated, yet when combined, it integrates the physical and virtual worlds.

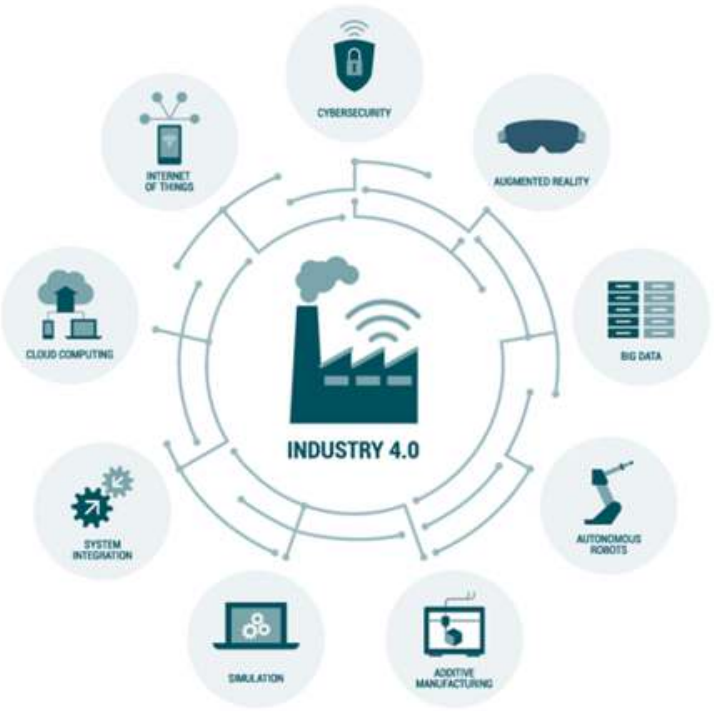

Figure 2. Industry 4.0 - The Digital Transformation Source at https://www.i-scoop.eu/industry-4-0/

Many experts cite the German Industry 4.0 platform when discussing the subject of industry because Germany is often regarded as the first country to implement industry 4.0 technology. Due to its substantial 
research, development, and manufacture of revolutionary manufacturing technology, as well as the management of complex industrial processes, Germany has one of the world's most competitive manufacturing industries. Industry 4.0 will bring together machinery, warehousing systems, and manufacturing facilities to form a global network of Cyber Physical Systems (CPS). In a manufacturing scenario, this CPS is made up of smart machines, storage systems, and production facilities that can modify data, activate activities, and control each other autonomously. Smart Factories have begun to emerge, employing a new technique to quickly service the demands of a single customer without having to wait for a certain number of orders to keep production costs down. [10].

The characteristics of the Smart Manufacturing and Industry 4.0 revolutions are as follows: [21]

a. Cyber Physical Systems (CPS): a combination of physical and virtual worlds

b. Internet of Things (IoT): communicates objects based on Internet technology. In addition, detection and identification uses IPv6 addresses (128 bit address space). The advantage of IoT is that the detection, identification and location of physical objects can be directly related through Internet connectivity

c. Internet of Services (IoS): provides Internet-based services and is able to conceptualize a specific product on request. With IoS, interactions between humans, machines, and systems can increase value.

d. Internet of Data (IoD): data is managed and shared using Internet technology. This is because CPS produces big data.

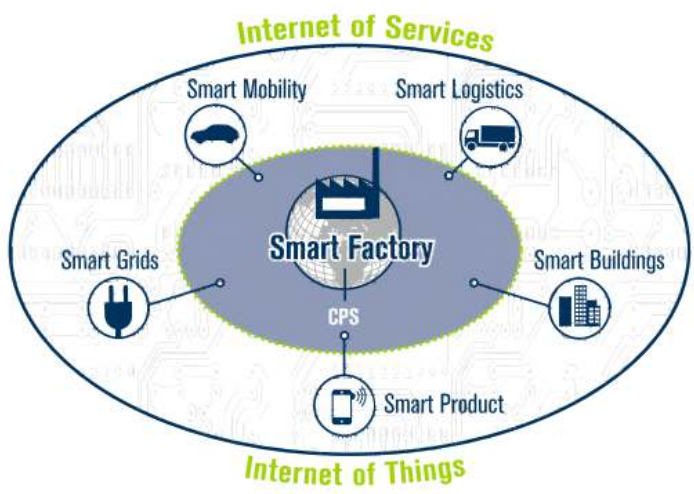

Figure 3. Industry 4.0 and smart factories as part of the Internet of Things and Services

Source at: Industry 4.0 Platform of Germany [10]

Industry 4.0 will address and solve some of the world's current concerns, including resource efficiency and energy, urban production, and population shifts. When work is organized in such a way that changes in demography and social aspects are taken into consideration, Industry 4.0 allows for higher productivity and long-term resource efficiency. Flexible work environments will allow employees to better balance their job, personal lives, and professional development, resulting in a better work-life balance.

Some of the things that resulted from Industry 4.0 were robots, self-driving vehicles, 3D printing, advanced manufacturing systems, data collection sensors, industrial cellular devices and nanotechnology [4]. Thus, factories in several countries began to use robots to run their production machines so that production became more stable, faster, and many more. For example in Indonesia as a developing country, the search results of Tempo magazine, assembling cars using robots at the PT Suzuki Indomobil Motor factory and PT Daihatsu, West Java Province. The use of robots is carried out at the stage of welding and painting. The robots were imported from Japan at high prices but were able to increase production by $50 \%$. In the textile factory owned by PT Sri Rezeki Isman (Sritex) in Central Java yarn spinning is also carried out by robots. Gross sales increased by $33.41 \%$ compared to the year before using robots. In addition to the goods industry, service industries such as ticket sales and banks have also used a fully automated digital system. [22]

\section{ENVIRONMENTAL DAMAGE}

Human civilization changed drastically after science developed rapidly with the discovery of technology that was increasingly sophisticated. The change lies beneath the higher level of technology, the more ambitious humans are to exploit and conquer nature.

On the other hand, the industrial revolution with technology advancement is able to guarantee health and provide high life rates. In 1806 the total population of the world had only reached 1 billion. Gradually the population rose to 2 billion in 1927 and rose again to 3 billion in the 1960s. Only in less than half a century or between 1960-2000, the world's population had increased to 6 billion people [23]. In 2017 the world population reached 7.6 billion and is expected to reach 8.6 billion in 2030 and then increase by 9.8 billion in 2050 and 11.2 billion in 2100 [24].

But on the other side, the increasing number of people has boosted not only the quantity of population but also the quality of human life styles that are increasingly lavish and uncontrolled levels of consumption. From time to time the resources continue to be exploited and pollution continues to increase sharply, as a result the environment is damaged and more human-caused disasters. The irony is that prosperity does not improve further, the gap between community groups is getting wider, the clash of civilizations and wars is increasingly common, immorality and moral damage are rampant. The environment as a carrying capacity of civilization experiences many pressures and damage continues to increase [23]. 
According to Drath and Horch the challenges that will be faced in are risk of natural disasters and the demands of environmental friendly technology application [6]. It implies that if the use of technology in industrial 4.0 activities is not properly controlled and managed, the risk of natural disasters as a result of environmental damage is inevitable.

Environmental damage and natural disasters that occur at this time are not solely natural factors but because of unwise human activities in utilizing natural resources. Environmental activists, especially those who embrace the Deep Ecology paradigm, assume that modernization and technology mean human greed for nature. The tendency of modernization to mobilize the accumulation of capital and natural use as much as possible is considered to have the effect of encouraging human greed for nature. Gorz argues that economic growth should be able to guarantee prosperity and wealthy, it turns out that more new desires that will be never satisfied so that it will lead to a deadlock that is not merely economic, but lead to human alienation to nature [25].

The global environmental crisis is happening as a result of increasing development. Since the Industrial Revolution, which began in the 1750 s, there have been many changes positioning humans with their technology to dominate nature. Humans develop technology and a variety of machine tools that consume high amounts of energy and resources, while causing huge environmental damage and pollution [23]. Development activities supported by advanced technology has brought human behavior to compose the environment and exceeded the limits of its capacity. Modernization of development has brought human change in terms of quality of life and consumptive lifestyles as well as an increase in the quantity of the population that requires high resources and energy support [26].

Therefore, in order to avoid Industrial Revolution 4.0 becomes the next mistake as previous industrial revolution which have proven to contribute to environmental damage, the Government as the holder of legislative power must form a regulation so that industrial technology 4.0 not only increases the industrial value of a country but also protects the environment to remain sustainable until the next generation.

\section{REMOVAL OF THE ROLE OF HUMANS}

Today We live in a very connected world, where information, ideas and people can mobilize and communicate way faster than before. We also live in a world that becomes more inequal. A phenomenon arises from massive changes in the labor market [7].

Behind its success, technology 4.0 automatically erodes the workforce. This is because reduction in human labor in the production process. Some companies admitted to training their employees to be transferred to other divisions or operate machinery. However, if they were still incapable after training the employee was automatically be dismissed [22]. Industry 4.0 is determinated with Mobile, Cloud, Big Data analytics, Machines to Machines, Human Interaction to Machines, 3D Printing, Robotics and many more requiring performances with special expertise. Experience, knowledge, skills and education are very important for human capital at work that is basically the main point in preparing "human capital" in carrying out Industry 4.0. However, nowadays there are still many countries or organizations that are only capable of being spectators without being actively involved in Industry 4.0 activities. [21].

If domestic workers are not accommodated by the state and company because they are replaced by machines they will migrate to other countries that still need human labor. As a result, the productive age in the country will decrease. However, if the country does not have the opportunity to migrate to another country, the country will be increasingly burdened with an increase in unemployment rates. In effect, the goal of the state to become prosper country will not be achieved. The negative effect that often occurs due to the industrial revolution is the increasing crime because of the increasing population but there is no adequate employment and availability of natural resources.

Industry 4.0 one of which is to produce self-riding vehicles. What will be a big question is what if there is a road accident. Who will be responsible? Who will be a legal subject? Can the future law be able to replace humans as legal subjects?

Humans are the noblest creatures because they are given reason and (heart) feelings. The advantage of heart over reason is that the heart is able to see all the nature of truth. Intellect can only capture knowledge in a limited way, for instance knowledge that is only rational and empirical through the senses and reasoning power (ratio), while the heart is able to capture the truth of 'knowledge' indefinitely [28]. Heart that can be relied upon to control mind is the heart that comes from understanding religion. Science and religion are human achievements, which in essence, emerged from the same passion so that humans can survive answering various kinds of challenges that humans have always faced in their existence. Wijaya [29] states that Science and religion are the ways humans have to recognize the mysteries of truth and reality within a broader structure of knowledge. So, epistemologically, science and religion are the types of knowledge that humans have among other types of knowledge: common sense, myth, ideology, and art.

Mind that is controlled by the heart that is based on faith in God through religion is actually capable of showing truth to humans because it produces creativity, taste, and intention. It is reason that differentiates humans 
from other creatures. Industry 4.0 that creates robots with artificial intelligence must be reviewed. Because robot is only a machine that does not have a heart even though its intelligence can be made beyond human intelligence. Whether artificial intelligence will later prosper human beings or otherwise will threaten humans.

\section{INDUSTRIAL LAW}

Industry 4.0 has opportunities such as the industrial revolution happened before which will have a negative impact on both the environment and humanity. Therefore, industrial law 4.0 is a law prepared for future so that there will be no legal vacuum or legal conflict if conflict among humans or humans with the environment happens.

Good law is a law that welfare human beings and preserve nature. Global economic imbalance due to industrial pressure causes poverty, unemployment and crime. The welfare state concepts and programs that have been echoed by many countries are considered to be unsuccessful in realizing justice, peace and mutual prosperity in life. According to Elviandri, et al. [27] This assessment of failure is based on the concept of capitalism, which assesses welfare solely in terms of material gain. The inability of the market and the state to improve people's welfare, capitalism and neoliberalism do not give a space for the state to implement social justice programs. Because the welfare state has failed to bring citizens closer to just welfare, future industrial law must be revised to reflect the paradigm of good law, which protects people and the environment through the creation of a welfare state based on maqashid al-sharia.

Therefore, a fundamental paradigm shift for industrial law can be based on religion. Prophetic law as one of the pillars in the development of Islamic law relating to maqashid. Maqashid itself is the basis in reformulating Islamic law through a discipline of the rules of fiqh. The existence of benefits (al-mashlahah) is the main indicator for the maqshid al-sharia to emerge. So, with al-mashlahah (benefit) there will be no mafsadat (destruction) to humans and nature [30]. Industrial law in the future is a law that must provide benefits to both nature and humans.

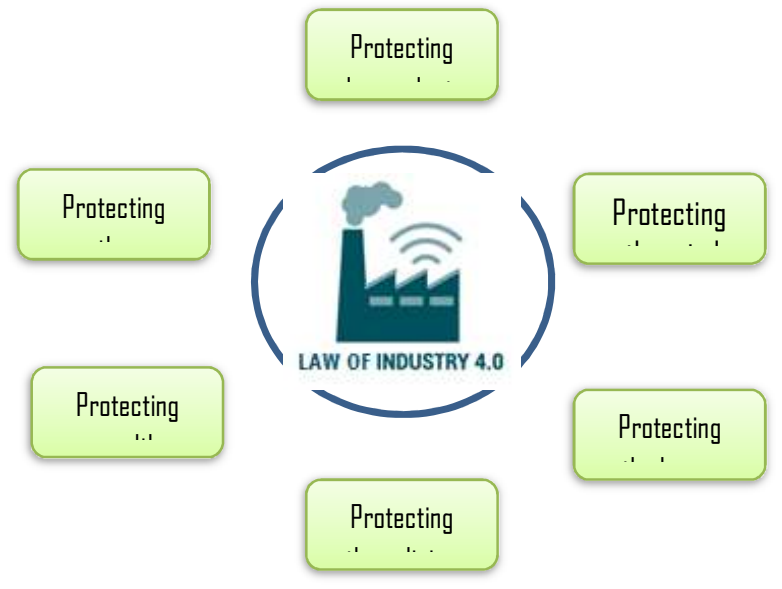

Figure 4. Law of Industry 4.0

Source: referenced from various sources

The contemporary theory of maqashid al-sharia referenced from Al Shatibi [31] is as follows:

a. Protecting offspring (al-nasl): law oriented to family protection and lineage nasab. Industry creates products that will not stimulate humans to engage in free relations that will damage the family lineage.

b. Protecting reason (al-'aql): law oriented to the protection of human reason. Industry directs production that educates humans and does not cause damage to human reason.

c. Protecting honor (al-adiradl) and soul (al-nafs): laws oriented to maintain and protect human dignity and human rights. Industrial activities and products will not make human beings lose their dignity and rights.

d. Protecting religion (al-Din): the law maintains, protects and respects the freedom to have religion and trust. Industry does not keep people away from religion because of the failure of the industrial revolution that only aims at material so that it does not control the behavior of humans as strongly as the religion that has been proven to be a control of human behavior.

e. Protecting wealth (al-mâl): the law must prioritize social care; pay attention to economic development and growth; encourage human well-being; eliminate the gap between the rich and the poor. Laws that regulate industrial activities must not only provide space for the owners of capital so as to create security and close human access to develop their business

f. Protecting the Environment (al-bi'ah): the law must balance industrial activities with environmental sustainability. Industry may not exploit excessive nature, causing environmental damage and disasters such as industrial activities that have occurred before such as global warming caused by the impact of activities and products of an industry. 


\section{CONCLUSION}

Creating a conducive industrial climate can do the purpose of the state for the welfare of its people. Development of knowledge enables to create technological advancements, including in industrial activities and products. Countries in the world are competing to develop industry 4.0 not only to meet domestic needs but also to be able to supply other countries.

Industry 4.0 was created to become an idea of an industrial revolution that utilizes the internet connection to be able to exceed the limited boundaries such as electric and clean vehicles, renewable energy, the smartgrid, IoT / IoE, Big Data, robotics, AI, fintech, blockchain, VR , cybersecurity, and agtech / agricultural innovation. Learning from previous industrial revolutions, the state must not only be oriented to the profit and progress of the industry without thinking of other things such as human welfare and natural sustainability.

The state with its authority has the right to regulate all industrial activities and results in order to bring benefits that aim to protect offspring, reason, honor, religion, wealth and the environment. The state must make industrial legal policies that harmonize nature, technology and humans.

\section{REFERENCES}

[1] I. A. Nurani, "The Technology Of Tools And Ornaments Production At Gua Kidang, Blora," Berk. Arkeol., vol. 35, no. 1, pp. 1-24, 2016.

[2] A. B. M. bin A. B. I. Al-Seikh, "Lubaabut Tafsiir Min Ibni Katsiir," Tafsir Ibnu Katsir, Translation by M. Abdul Ghofar. Pustaka Imam As-Syafi'i, 2005.

[3] K. C. Lin, J. Z. Shyu, and K. Ding, "A Cross-Strait Comparison of Innovation Policy under Industry 4. 0 and Sustainability Development Transition," Sustainability, vol. 9, no. 786, pp. 1-17, 2017.

[4] D. Vuksanović, Jelena Ugarak, and D. Korčok, "Industry 4 . 0: The Future Concepts And New Visions Of Factory Of The Future Development," in International Scientific Conference on ICT and Bussines Related Search, 2016, pp. 293-298.

[5] F. Baldassarre, F. Ricciardi, and R. Campo, "The Advent Of Industry 4.0 In Manufacturing Industry: Literature Review and Growth Oportunities," DIEM, pp. 632-643.

[6] R. Drath and A. Horch, "Industrie 4.0: Hit or Hype ?," IEEE Ind. Electron. Mag., vol. 8, no. (2), pp. 56-58, 2014.

[7] Klaus Schwab, The Fourth Industrial Revolution. Switzerland: World Economic Forum, 2016.
[8] H. Kagerman, W. D. Lukas, and W. Washier, "Industrie 4.0: Mit dem Internet der Dinge auf dem Weg zur 4. industriellen Revolution," VDI nachrichten, Germany, p. 13, 2011.

[9] S. Heng, “Industry 4.0: Upgrading of Germany's industrial capabilities on the horizon," Germany, 2014.

[10] H. Kagerman, W. D. Lukas, W. Washier, and J. Helbig, "Recommendations for implementing the strategic iniatitve Industrie 4.0," Germany, 2013.

[11] H. Prasetyo and W. Sutopo, "Industry 4.0: Review Aspect Classification and Direction of Research Development," J. Tek. Ind., vol. 13, no. 1, pp. 1726, 2018.

[12] S.-W. Lin, B. Miller, S. Schrecker, and J. Molina, "Industrial Internet Reference Architecture," 2015.

[13] "Industry of the future : New Face of Industry in France," Government of France Republic, 2015. [Online]. Available: https://de.ambafrance.org/Vorstellung-desneuen-franzosischen-Plans-Industrie-du-Futurin-der-Botschaft. [Accessed: 15-Jan-2009].

[14] "Quality revolution needed for 'Made in China,", Government of China, 2016. [Online]. Available: http://english.gov.cn/policies/policy_watch/2016/ 08/26/content_281475426397196.htm. [Accessed: 15-Jan-2019].

[15] A. Rojko, "Industry 4.0 Concept: Background and Overview," iJIM, vol. 11, no. 5, pp. 77-90, 2017.

[16] “Making Indonesia 4.0," Indonesian Ministry of Industry, 2018. [Online]. Available: http://www.kemenperin.go.id/download/18384. [Accessed: 01-Jan-2018].

[17] "The Government Issues 10 Surefire Steps to Face the Industrial Revolution 4.0," Indonesian Ministry of Industry, 2018. [Online]. Available: http://www.kemenperin.go.id/artikel/19169/Pem erintah-Keluarkan-10-Jurus-Jitu-HadapiRevolusi-Industri-4.0. [Accessed: 01-May-2018].

[18] H. Lasi, P. Fettke, T. Feld, and M. Hoffmann, "Industry 4.0," Bus. Inf. Syst. Eng., vol. 6, no. 4, pp. 239-242, 2014.

[19] Philipp Gerbert et al., "Industry 4.0: The Future of Productivity and Growth in Manufacturing Industries," (C2019 Boston Consulting Group, $2015 . \quad$ [Online]. Available: https://www.bcg.com/publications/2015/engineer ed_products_project_business_industry_4_future _productivity_growth_manufacturing_industries. aspx. [Accessed: 11-Jan-2018].

[20] R. Neugebauer, S. Hippmann, M. Leis, and M. Landherr, "Industrie 4.0-From the Perspective of 
Applied Research.," in Procedia CIRP, 2016, vol. 57, pp. 2-7.

[21] J. E. Agolla, "Human Capital in the Smart Manufacturing and Industry 4.0 Revolution," in Digital Transformation in Smart Manufacturing, 2018, pp. 41-58.

[22] Tempo, "2009 Economy Outlook: Revolution 4.0 Is a Key," PT Tempo Inti Media, Jakarta, pp. 7888, Nov-2019.

[23] M. Baiquni, "Industrial Revolution, Population Explosion and Environmental Problems," J. Sains dan Teknol. Lingkung., vol. 1, no. 1, pp. 38-59, 2009.

[24] "World population projected to reach 9.8 billion in 2050 , and 11.2 billion in 2100," Departement of Economic and Social Affairs United Nation, 2017. [Online]. Available: https://www.un.org/development/desa/en/news/p opulation/world-population-prospects-2017.html. [Accessed: 12-Dec-2018].

[25] A. Gorz, Ekologi dan Krisis Kapitalisme. Yogyakarta: Insist Press, 2002.
[26] Absori, "Enforcement of Environmental Law in the reform era," Ilmu Huk., vol. 8, no. 2, pp. 221$237,2005$.

[27] Elviandri, et al "The formulation of welfare state: the perspective of Maqāșid al-Sharī'ah", Indonesian Journal of Islam and Muslim Societies, Vol. 8, no.1, pp. 117-146, 2018

[28] A.A. Cholik, "Intellect and heart relations according to al-Ghazali (Relasi Akal dan Hati menurut al-Ghazali”, Jurnal Kalamah, Vol. 13, No. 2, pp.287-310, September 2015

[29] C.A. Wijaya, "Ilmu Dan Agama Dalam Perspektif Filsafat Ilmu", Jurnal Filsafat, pp.174-188, Vol. 40, No. 2, Agustus 2006

[30] Absori, Transformation Of Maqâshid Al-Syarî'ah (An Overview of the Development of Islamic Law in Indonesia), al-Ihkâm, Vol.11, No.1, Juni 2016

[31] Absori, et. Al, "Hukum Profetik, Kritik terhadap Paradigma Hukum Non Sistemik”, Yogyakarta: Genta Publishing, 2015. 